\title{
A comparison of Central Bank and Judicial Independence
}

\author{
George Tridimas
}

University of Ulster, School of Economics and Politics, Shore Road, Newtownabbey, Co. Antrim, BT37 0QB, UK, Tel: +44 (0) 28 90368273, E-mail: G.Tridimas@ulster.ac.uk

\begin{abstract}
As successful markets are founded on the rule of law and monetary stability, the paper investigates whether judicial independence (JI) and central bank independence (CBI) are positively correlated. After analysing and comparing the meaning, rationale and institutional arrangements for JI and CBI a more nuanced pattern of similarities and differences emerges. Estimation of the statistical significance of the coefficient of correlation between JI and CBI for an international sample shows that there is no significant correlation between indicators of legal independence but a significant correlation between indicators of actual independence.
\end{abstract}

Key words: Central Bank Independence; Judicial Independence; Judicial Review of Policy; Delegation; Credibility; Rule of Law; Accountability; Political Insurance.

JEL Categories: D72; D78; E58; P16

18 March 2008 Preliminary draft Please treat accordingly

Comments welcome 


\section{A comparison of Central Bank and Judicial Independence}

\section{Introduction}

The development of a legal and a monetary system are closely interconnected: The successful operation of markets is founded on the rule of law and monetary stability. Both, however, are threatened by opportunistic governments which may violate the rights and freedoms of citizens and generate inflation to pursue their own objectives. Application of the rule of law and monetary stability require that credible constraints are imposed on the discretionary powers of the government so that it will not transgress against citizens and it will not engage in inflationary finance. Adherence to the rule of law, monitored by an independent judiciary, typically encapsulated by the independence of the highest court of a country, and commitment to price stability, overseen by an independent central bank, provide two such credible mechanisms of constraining the government.

Delegating decision making to central bankers and judges who are insulated from shortrun electoral considerations allows them to focus on the long-run interests of citizens and to disregard myopic, short-run, concerns of politicians. However, dispute resolution by courts (especially when they rule against measures enacted by a legislature representing an electoral majority), and monetary policy making by appointed officials may go against deep-seated notions of majority decision making and democratic accountability. The various institutional arrangements (or lack thereof) aiming to insulate judges and monetary policy officials from government interference, represent the solution to this dilemma between accountability and credibility. On this basis Goodhart (2002) argues that in any given country there is some kind of common thread running through the arrangements underpinning judicial and central bank independence. In other words, if the origins of the problem are common, so must be the solution. If this reasoning is correct, then one predicts that judicial independence (JI) and central bank independence (CBI) must be closely associated, in the sense that countries which grant higher independence to their courts also grant higher independence to their central banks. The purpose of the present study is to investigate the validity of this claim. 
After discussing how its precursors saw the analogy between CBI and JI, Section II scrutinizes the arguments by comparing the rationale for judicial and central bank independence and identifies a number of similarities and differences in their foundations. It moves on to examine the institutional arrangements underpinning JI and CBI focusing on the issues of organisation, policy procedures and jurisdiction, control of policy instruments, finality of the decisions of supreme courts and central banks and their accountability. At the theoretical level a more nuanced relation between CBI and JI emerges from this comparison. Using an international sample Section IV finds that measures of legal CBI and JI are not correlated, while measures of actual CBI and JI are positively correlated. Section V concludes.

\section{Comparison of Central Bank Independence and Judicial Independence}

\section{$1 \quad$ A review of antecedents}

The analogy between CBI and JI alluded above has first been drawn in an earlier study by Goodhart (2002). He notes that in primeval societies the social basis of laws and money were closely linked. ${ }^{1}$ He then argues that governments delegate policy making to an independent central bank and an independent judiciary because of lack of credibility of government's commitment to keep prices stable and to uphold the law. ${ }^{2}$ Acknowledging that unelected judges and central bankers may abuse the powers delegated to them, he argues that the requirement for transparency (the obligation to explain their decisions) acts as an effective check on such tendencies. ${ }^{3}$

\footnotetext{
1 "Both the law and money are social institutions... Indeed it is possible that both initially evolved for quite similar reasons. The key factor common to both is the need for mechanisms to keep the peace, to prevent feuds ...” (p.195)

2 “...many such reasons are common and similar for both the judiciary and the central bank (p.199) ... An independent judiciary is a commitment device (on both the government and the judiciary) that the law will be interpreted impartially and without (covert) pressure from vested interests. By exactly the same token, ... the central bank acts as a commitment device, both on the government to accept the implications of its public objectives - or change them publicly - and on the central bank to act impartially, open and honestly.” (p. 200).

3 "...how is the potential for abuse of power to be constrained? One key mechanism is transparency.” (p.201)
} 
In a later and as yet unpublished contribution, Goodhart and Meade (2003) examined the analogy between CBI and JI by comparing and contrasting the UK Law Lords (the highest UK court) and Monetary Policy Committee of the Bank of England with their counterparts from the USA, the Supreme Court and Federal Open Market Committee, and the EU, the European Court of Justice and the European Central Bank. They found that in each of the two countries as well as the EU there exist many broad similarities between the procedures for appointment and decision making in the legal and monetary policy organs, but important differences across the two countries and the EU. ${ }^{4}$ Specifically, for both CBI and JI they characterise the US as combining goal-independence with politicisation of appointments, while they consider the UK as combining operational independence with appointments which emphasise technical expertise. In both countries the members of the decision making bodies are individually accountable for their opinions. On the other hand, they depict the EU as combining goal independence with a collectivist (or centralized) procedure of decision making, in the sense that, neither voting records nor dissenting opinions of the members of the independent policy bodies are published. They argue that these differences are explained by the solutions that different polities adopt to address the dilemma involved when powers are delegated to unelected independent bodies. ${ }^{5}$

These two papers explain that the delegation of monetary policy to an independent central bank came from the recognition that price stability is the only reasonable objective for monetary policy (since in the long-term monetary policy can only determine the rate of inflation) and that credibility of commitment to such objective is enhanced when the objective is pursued by a central bank independent of political control. However they do not elaborate on the claim that delegation to an independent judiciary is also attributed to the lack of credibility of a government's declaration to maintain the rule of law. The

\footnotetext{
4 "We were both surprised and impressed by the degree to which the comparative decisionmaking procedures in the law and in monetary policy appeared at roughly similar points along this (individualistic/collectivist) scale in the UK and USA, (and also, as far as we could ascertain, in Europe), despite the institutional evolution of the two sets of systems (monetary and legal) being quite separate. Our surmise is that there may be a common thread within the "national" circumstances of these countries (if the EU can be so described), which leads to a similar kind of response in setting decision-making procedures in each case.” (p.24)

5 "In the UK, they traditionally did so by minimising such independence; in the USA, by the politicisation of appointment; and in the EU, by the committees maintaining a common front in the face of the politicians.” (p.31-32)
} 
latter, in turn, is explained by Feld and Voigt (2003) who study the benefits of an independent judiciary for economic growth. They argue that government proclamations to protect the property rights of private individuals are also subject to a credibility problem when there is no third party to rule whether such transgressions have taken place. ${ }^{6}$

Similar arguments about the analogy of central banks and highest courts in transition economies permeate the study of Salzberger and Voigt (2002) ${ }^{7}$, who after examining the arrangements for JI and CBI in eight transition economies (Bulgaria, Czech Republic, Estonia, Hungary, Poland, Romania, Russia and Slovakia) they point to a positive correlation between the two. ${ }^{8}$ More recently, Hayo and Voigt (2007) again reiterate the view that CBI and JI are ways to increase government credibility. ${ }^{9}$

The claim about the an analogy between JI and CBI is based on two main arguments: First, that CBI and JI rest on the same fundamental reason, that is, the credibility of government commitments, and second, the commonality of institutional arrangements to make central bankers and judges impervious to intimidation by the government. In what follows these two claims are investigated at length.

\footnotetext{
6 "It can be argued that there are a number of structural similarities between the role and effects of central banks and the judiciary. The most important similarity is probably that both the judiciary and a central bank can help the government to mitigate a credibility problem. That government runs into a time inconsistency problem if it does not delegate monetary policy is widely acknowledged (Kydland and Prescott, 1977; Barro and Gordon, 1983). ... [The] government also runs into a credibility problem concerning protection of property rights if there is no neutral and independent arbiter who has the power to adjudicate whether government action has remained within the letter of the law (i.e., the 'promises' of the government)”. (p.500)

7 "the creation of an independent [constitutional court and central bank] and the transfer of competence to that agency ... can be explained by [the same] constitutional structures and political considerations" (p. 27)

8 "a pattern of positive correlation between the two ... [where] countries that are ranked as having the more independent constitutional courts are also ranked as having the more independent central banks (the Czech Republic, Estonia and Poland)...” p.44.

${ }^{9}$ Regarding JI they write: "The creation of an independent judiciary can also be interpreted as an attempt to mitigate the problem of time-inconsistent preferences. For example, a government might announce at some point in time that it will enforce private property rights, hoping that private actors will invest later on. Once invested, government is subject to the (short-term) temptation to attenuate the investors' property rights. If a neutral third party (the judiciary) has the competence to ascertain whether any of the conflicting players has reneged on its promises, and to force them to make good on their promises, incentives to honor one's promises are substantially increased. It would thus seem that rational nation state governments should aim at increasing their credibility by creating independent judiciaries.” (p. 272)
} 
In the first instance it may be argued that the rule of law, and therefore $\mathrm{JI}$, is a precondition for CBI. The independence of the central bankers would be meaningless if the legislation which established it could be violated or ignored. To put it another way, it is the job of courts to rule on disputes about the authority of the central banks and safeguard the independence of central banks. ${ }^{10}$ On this account one may identify an important difference between the two: JI may exist without CBI, but not the other way around. This observation however, does not diminish the strength of the proposition that there is an analogy between the two, and it is in this light that we the analysis proceeds.

\section{A. $\quad \mathrm{CBI}$ and price stability}

In the standard model of CBI the need for an independent monetary authority arises from the incentive of the government to expand output and its inability to commit to a credible policy of zero inflation. For example, the government may wish to announce a policy of low inflation to influence the expectations of the private sector. However, after the private sector has acted upon the expectation of low inflation, the government has an incentive to generate surprise inflation in order to exploit short-term output benefits. Understanding that the government may be inconsistent in its policies over time, the private sector will not trust policy announcements of low inflation. Then, discretionary policy results in inflationary bias, that is, a high rate of inflation without any output gain. Formally, this result is obtained upon assuming that the government minimises a quadratic loss function defined over inflation and the deviations of output from its desired level, subject to a Lucas-type aggregate supply curve (or its analogue), where output rises with unanticipated inflation and expectations about inflation are formed rationally, and an equation which relates inflation to the money supply, considered as the instrument controlled by the monetary authorities. An independent central bank is a mechanism to solve the problem of inflation bias of discretionary policy. Appointing a central bank which is independent of the

\footnotetext{
${ }^{10}$ This is illustrated by the case of the central bank of Belarus; although the bank is endowed with a high degree of independence, after inflation increased dramatically, the finance minister whose policies were the cause of inflation had the president of the central bank jailed (reported in Hayo and Hefeker, 2002, who quote an earlier study of Hillman).
} 
political authority, (one which can set policy without political restrictions and interference), and more "conservative”, (that is, inflation averse) than the government results in a lower level of inflation offering a solution to the dynamic inconsistency problem (see Rogoff 1985; for recent reviews see amongst others Berger, de Haan and Eijffinger, 2001 and Cukierman, 2006a abd 2006b). In general, the econometric evidence suggests that for both developed and developing economies, actual CBI (that is, as actually implemented) is negatively related to inflation (see for example Cukierman, Webb and Neyapti, 1992; Cukierman, 1992; Alesina and Summers, 1993; Berger et al. 2001; de Haan and Kooi, 2000; and de Haan et al, 2003).

Note however, that as Hayo and Hefeker (2002) document, CBI is neither necessary nor sufficient for price stability. Fixed exchange rates, explicit inflation targets and inflation contracts for central bankers (which stipulate penalties for missing the targets) are amongst alternative policy arrangements for pursuing price stability. Moreover, the negative correlation between CBI and inflation found in empirical work does not necessarily indicate causality. Hayo and Hefeker (ibid.) argue that societies first decide whether or not they wish to pursue price stability and then they choose which policy institution to adopt in order to accomplish their objective. As preferences differ across different societies, some societies may exhibit more inflation aversion than others. In this case causality runs from a society's preferences to CBI. In addition, drawing on Posen (1993), they suggest that stronger inflation aversion may originate from the self interest of the financial sector, which is presumed to benefit more from low than high inflation ${ }^{11}$, and may be in a position to apply pressure to the government for policy arrangements which promote and support its interests. In this case CBI arises endogenously as the outcome of the successful lobbying of the financial sector. If CBI is neither necessary nor sufficient for price stability, then why some inflation-avert countries still choose to pursue this objective by CBI rather than an alternative arrangement? Hayo and Hefeker (op. cit.) suggest that an independent central bank may enjoy more credibility than the government when withdrawal of independence is politically costly. This is usually the case in political systems with strong checks and balances, as for example in countries where passing legislation requires the consent of more than one veto players, or there is a federal structure, or political freedoms are protected.

\footnotetext{
${ }^{11}$ As financial intermediaries borrow short and lend long, they may suffer heavy losses with inflationinduced changes in interest differentials. Moreover, as inflation will eventually be followed by contraction, financial intermediaries may suffer additional losses from failing borrowers
} 


\section{B. JI and the rule of law}

The need for an independent judicial authority arises from the importance of resolving disputes and maintaining the rule of law for a functioning market economy and a free society - see Manne (1997) for a recent detailed presentation of the relevant arguments. Disputes (which in general originate from incomplete information about preferences and technologies, random shocks to the economic environment, imperfect foresight, conflicts of rights and ambiguous contract language) may emerge between citizens and between the citizen and the state. In disputes between the citizen and the state, those in power may abuse the rights of the losing minority through restrictions on freedoms and expropriation of property. A basic element of the rule of law is that laws apply equally to all citizens under the same set of relevant circumstances, so that all people are governed by the same rules. Resolution of disputes by enforcing the law and interpretation of the law itself (including the constitution) is entrusted to an independent judiciary with the power to issue binding rulings. Judicial independence means that the judiciary enforces the law and resolves disputes without regard to the power and preferences of the parties appearing before it, including those of the government which is often a litigant in dispute resolution and always in regulatory and criminal disputes (La Porta et al, 2004). Further, judicial review of policy is the examination of the policy measures passed by the legislature and enacted by the executive branch of government for their compatibility with the constitution (Stone Sweet 2002). Judicial independence is different from judicial review. A court may be politically independent but have only limited rights to review the policy measures of the executive; English courts, at least until the recent incorporation of the European Convention on Human rights, were a good example of this case. Of course, policy review is meaningful only when conducted by an independent court. Judges must then be shielded from the threat of coercion by the executive and corruption from private litigants. ${ }^{12}$ Analytically, the gains from the operation of the judiciary are studied by applying game theoretic models to the process of policy making (see amongst others, Gely and Spiller, 1990, Ferejohn and Weingast, 1992, McNollGast, 1995, and Hanssen, 2000). Formally, a game theoretic framework is adopted, which pits the judiciary against other strategic players such as the executive and / or the

\footnotetext{
12 See Glaeser and Schleifer (2002) for a formal treatment showing that when bullying and intimidation of judges by local powerful interests is moderate, a system of independent juries (as in the common law tradition), yields higher social welfare than a system of judges controlled by the sovereign (which characterizes the civil law tradition).
} 
legislative arms, each player has a quadratic loss function defined over one or more policy variables and policy is decided in a stochastic environment. However, contrary to the macroeconomic model, where the objective function of the policy makers is specified as a function of inflation and output, the arguments of the objective function of the judges are left unspecified. ${ }^{13}$ Nor is there an equivalent to the Lucas supply curve to relate the policy issues over which the judiciary deliberates.

On the above account, some important differences between CBI and JI emerge. First, the meaning of the rule of law is considerably more general, and thus vague, in comparison to the economic objective of the central bank. Price stability which can in practice take the form of a specific numerical inflation target (even though the exact definition of what items are to be included in the composition of the price level and what constitutes price stability are matters of some debate). Quantification of the price stability goal is therefore possible and does take place in practice. On the other hand, quantification of the rule of law is more problematic. It is a multi-dimensional concept comprising a range of attributes pertaining to the administration of justice. For example, in constructing a measure of the rule of law for an international sample of 209 countries Kaufmann, Kraay and Mastruzzi (2005) include indicators which measure the extent to which citizens trust the rules of society and abide by them. Among other these cover fear, frequency and violence of crime; trust in the police; the effectiveness and the predictability of the judiciary including fairness of judicial process, its speed and trust of it; and the enforceability of contracts and protection of rights. High respect for the rule of law implies high sores on all these accounts; however, the potential of conflict between some of those attributes may not be ruled out. It is not then clear what kind of trade-offs between them, if any, are acceptable.

Be that as it may, there is a related but potentially more serious problem with the concept of the rule of law. There is a consensus about the benefits and therefore the desirability of price stability, but much less agreement about what is a "good" law. Price stability is good for the economy for it increases welfare. However, application of the rule of law does not necessarily imply that a "good" law is applied. The law may privilege the interests of

\footnotetext{
${ }^{13}$ This injunction was first made by Mueller (1996) who writes (p. 294): “An explanation of the objectives of the judiciary remains one of the great lacunae in the public choice - rational choice literature. This lacunae hampers greatly the development of incentives to induce the judiciary to pursue normative goals like advancing citizens interests” (emphasis in the original).
} 
whomever the lawmakers wish to favour. As Shapiro (2002) put it "The rule of law requires that the state's preferences be achieved by general rules rather than by discretionary-arbitrary-treatment of individuals" (p.166). He offers the courts of the apartheid era in South Africa as an example. There is little doubt that at the time they were upholding the law of the land, but to the black population they could hardly appear as neutral and independent arbiters of interests between the black and white sections of the population.

We may summarize the above account by concluding that the rule of law relates to following due process for pursuing policy objectives, while price stability is itself a policy objective.

Second, unlike the theoretical macroeconomic model used to explain the benefits of central bank independence and conservativeness vis-à-vis inflation, there is no standard formal model of the credibility function of the judiciary. Specifically and as already mentioned, contrary to the standard macroeconomic model of a short-run expectationsaugmented aggregate supply curve and rational expectations, there is no equivalent algebraic formulation of a causal relation of the rule of law and JI on output and / or individual freedoms.

Despite the above differences, both CBI and JI share the common characteristic that they offer a mechanism to protect the citizens from the discretionary powers of public officials who may divert resources for their own benefit (or more generally, the political interests they represent). On this account, delegation of policy powers addresses an underlying conflict of the government versus the citizens. As a result the principals - citizens may increase welfare by delegating authority to a policy agent whose preferences differ from those of the government. This further implies that when two different political parties with different preferences about inflation fight an election for control of the government, they agree to appoint central bankers with policy preferences different from their own, specifically central bankers who are more averse to inflation than both parties. If the credibility motive drives delegation to courts, an analogous presumption can be made for appointing judges, that is, the competing parties agree to appoint judges with policy preferences different than their own. 


\section{Conflicts of interests, political insurance and independence}

More recently, a number of contributions depart from the credibility interpretation of JI and consider court independence as an insurance mechanism in response to electoral uncertainty. An independent judiciary with the power to reign in the proclivities of the winning majority and annul policy measures incompatible with the constitution protects the rights of citizens from the "tyranny of the majority". Judicial independence is then valued by citizens and politicians when no party is expected to permanently dominate the electoral game; see amongst others Ramseyer (1994), Ramseyer and Rasmussen (1997), Vanberg (2001), Ginsburg (2002), Padovano et al. (2003), Stephenson (2003), Hanssen (2004a), Maskin and Tirole (2004) and Tridimas (2004) and (2005). The insurance function of the judiciary is analysed by employing game theoretic models of policymaking in settings characterised by asymmetric information, where political parties compete for the right to decide policy in elections whose outcomes are uncertain and power is separated between different strategic government branches including the judiciary. In this framework, delegation of decision making power to a judiciary offers a mechanism to resolve conflicts between citizens vying for political control, rather than between the government and the citizens taken as a unified group.

The insurance rationale leads to different predictions about the type of agent appointed by the principal in comparison to the credibility rationale. In the political insurance framework given the probability to win an election and the differences in the preferences of competing political groups, each political group is better off when an agent decides policy, but prefers to delegate policy making to an agent which has preferences similar to its own. This is the well known "ally principle" of delegation, see for example Bendor et al. (2001) for details. That is, in contrast to the credibility rationale of delegation (where the competing principals agree on the conservativeness of the preferences of the agent they would like to appoint), in the political insurance rationale of delegation political principals disagree on the preferences of the agent they would like to appoint as each one prefers an agent with policy preferences closer to its own.

Although it does not view CBI as an insurance mechanism, CBI scholarship is not oblivious to the influence of politics on the decision to endow the monetary authorities with autonomy. A distinct volume of research addresses this issue. Inflation can have 
diverse distributional consequences, when, for example, borrowers gain from the erosion of the real value of their debts while creditors lose. In this case the pursuit of price stability may privilege some citizens against others and CBI may be considered as a mechanism which is not independent of specific economic interests. As already mentioned, this observation led Posen (1993) to suggest that the financial sector which benefits from price stability will press the government for CBI (see also McNamara, 2002).

Studying CBI from the vantage point of conflicting interests, Cukierman (1994) argues that in a regime where parties alternate in office within the constitutional order, a political party in office may grant independence to the CB in order to restrict the ability of the opposition after it wins power to pursue its favorite policies. For example, if an incumbent, who supports price stability, worried that the party which supports monetary expansion and high spending will gain office, decides to delegate monetary policy to an independent central bank. However, in an unstable political regime where power changes occur irregularly through extra-constitutional means, like coups, the incumbent may be preoccupied with his own survival and decide to keep all levers of policy, including monetary in his own hands. These questions are further investigated in the works of Cukierman and Webb (1995), De Haan and Van’t Hag (1995), Bagheri and Habibi (1998), Moser (1999) and Keefer and Stasavage (2003).

Finally, one may wonder whether there is an interest group analogy between CBI and JI. That is, in the same way that CBI was considered as supported by the financial sector, can JI also be, partly at least, considered as the product of interest group politics? Shapiro (2002) answers this question affirmatively. He argues that, given the legal knowledge and expertise required in resolving disputes, the legal epistemic community of practicing lawyers, judges and law academics, forms an effective, albeit loose interest group, which benefits a great deal, both financially and in terms of prestige, from the functioning of an independent judiciary. ${ }^{14}$ Thence, it is in the self-interests of the legal community to lobby the government for a judiciary which is independent of partisan controls. This intuition offers a promising avenue for further research.

\footnotetext{
14 "The epistemic community of law has an enormous self-interest in defending [the independence] of constitutional courts ... When constitutional courts enjoy great success, their success rubs off on all lawyers and courts” p.175
} 
The independence of central banks and judiciaries depends on the various arrangements which to various degrees may insulate or expose them to political pressure and intimidation. These arrangements encompass the organisation of central banks and judiciaries, their policy procedures and jurisdiction, control of the policy instruments, and finality of their decisions, and determine the degree to which the independent agencies are accountable for their behaviour.

\section{A. Organisation}

By organisational arrangements for CBI and JI we mean the appointment process and the conditions of service of central bankers and judges. Such arrangements include the power to appoint the members of the monetary policy making bodies and supreme courts, the procedures for their selection, confirmation and dismissal, the length of the term of their services, their financial autonomy, their number and the transparency of their deliberations. To a large extent, it is similarities between those arrangements, rather than any other attribute, which underpin the analogy between CBI and JI.

Central bankers and judges are more independent the less the government is involved in the process of their appointment, since government interference for partisan benefit reduces their ability to perform their duties impartially. In practice central bankers and highest court judges are appointed, but the degree of politicization of the appointment process differs from country to country. ${ }^{15}$ In a system where the government nominates such officials, judges and central bankers are more independent the larger the legislative majorities needed for their confirmation. However, officials are even more independent in a system where they are nominated by the relevant professional body, as for example when the judiciary nominates candidates from its ranks for positions in the highest court.

\footnotetext{
${ }^{15}$ See also Mueller (1996) for a detailed discussion. Popular election of judges for some lower courts takes place in a number of American states. Hanssen (2004b) investigates in detail the origins and development of five different procedures to select and retain judges, notably, partisan and nonpartisan election, gubernatorial and legislative appointment, and the merit plan, an appointment - election hybrid. There are no real world examples of popular election of central bankers.
} 
JI and CBI increase with the length of term of service of central bankers and judges, when they can only serve one term (or they are not seeking re-appointment), and when there are effective restrictions on the ability of the government to reduce their budgets. Under those conditions they can take a long-run view of the interests of the citizenry and act independently of the short-run electoral interests of the politicians.

Scholarship on JI has also identified the number of judges serving at the highest court as an additional influence, a factor which has been ignored by research on CBI. Feld and Voigt (2003) argue that an increase in the number of judges may decrease the influence of judges with preferences different to those of the executive branch, a motive behind President Roosevelt's threat to "pack" the US Supreme Court and French President d'Estaign's suggestion for each of the "big four" EU countries to appoint additional judge to the European Court of Justice - in the end none of these plans was carried out. However, a small number of judges may restrict the views put forward to resolve a dispute potentially risking the quality of judicial rulings - for details, see amongst others, Feld and Voigt (2003), and Tridimas (2004).

Transparency, the obligation to explain and justify decisions, enhances the independence of both central banks and judiciaries, as it increases publicly available information and obliges non-elected officials to fully justify their decisions (forcing therefore the accountability of non elected officials). Disclosure of the rationale behind a monetary policy measure decreases information asymmetries between the authorities and the public (in general, the public is assumed to be less well informed about the economic environment, and the preferences and strategies of the policy makers) and offers a valuable tool to influence the expectations of the public, raising the effectiveness of monetary policy. ${ }^{16}$ Similarly, disclosure of the reasoning behind a court ruling increases the public's information about the circumstances surrounding each dispute and the judges' interpretation of the law which influences future courses of action by private and state actors. In addition, such disclosure of judges' reasoning discourages politicians or other interested parties from trying to influence judicial outcomes. However, there is no

\footnotetext{
${ }^{16}$ Central bank transparency has motivated an increasingly growing volume of scholarly research. For a recent survey see Cukierman (2001) and Geraats (2002), while de Haan et al. (2007) introduce a collection of new research on the issue.
} 
consensus as to what constitutes the optimal degree of transparency. Should for example the central bank publish its forecast about the future state of the economy? Note that as stochastic shocks and expectations formation are crucial for the conduct of monetary policy, this issue is more relevant to CBs than courts. The literature on CB transparency has shown that the maximum level of information is not necessarily the optimum level for the efficiency of monetary policy. Nor is there agreement on how transparency should be implemented. Since monetary policy committees and judicial organs are collective bodies, the issue here is whether the assessments and voting records of the individual members of those bodies should be published. ${ }^{17}$

An interesting question is whether the drive for transparency is motivated by the requirement of political accountability, an issue which is taken up in sub-section E, or by any economic benefits independent of the former. The literature on JI seems to emphasise the role of transparency in enhancing accountability (see e.g. Cappelletti, 1983 and Shapiro, 2002). However, in her comprehensive survey of central bank transparency, Geraats (2002) concludes that “... central bank transparency ... has taken hold... because of its perceived economic benefits” (p. 561). This conclusion is probably to be expected from a branch of literature which has studied in detail and rigour the sources and forms of stochastic disturbances affecting economic outcomes.

\section{B. Jurisdiction}

For the judiciary, jurisdiction relates to the terms by which private agents (physical persons and legal entities) can access the courts to pursue a case and the competence of the courts to rule on cases and review legislation. The literature has also examined a range of issues here. ${ }^{18}$ (i) Whether ordinary courts can exercise judicial review of laws, as in the US system (which for this reason is referred to as a decentralized system), or only

\footnotetext{
${ }^{17}$ For example, keeping secret the voting record of judges may also have some advantages in the specific circumstances of supranational judicial bodies with the Court of Justice of the EU being an obvious case. The Court does not disclose how individual judges have voted and, contrary to the USA Supreme Court, dissenting opinions are not published. This secrecy protects judges against possible retribution from governments which lost their cases at the Court. In addition, if dissenting or minority views became known, governments which objected the ruling of the Court would be tempted, and find easier, not to comply with the ruling.

${ }^{18}$ See Epstein \& al (2001) and Ginsburg (2002) for extensive discussions.
} 
specialized constitutional courts have such rights, as in the centralized system characterizing European countries. (ii) Whether judicial review is concrete, or abstract. Concrete means that the constitutionality of a law is checked in a case which is actually litigated in front of a court; abstract means that the constitutionality of a law is checked without litigation involving the particular law. Closely related to this issue is whether review is carried out ex ante or ex post, that is, before or after the promulgation of a law. USA courts practice concrete ex post review, while the French Constitutional Court offers an example of abstract a priori review. In general, abstract and a priori review is more limited, as it is not based on a real case but on a hypothetical conflict and is conducted with less information about "facts". On the other hand, it has the advantage that it can eliminate unconstitutional legislation before it actually does any harm.

In general, the power of the judiciary as an independent arm of governance rises when individuals are granted more open access to the courts, and ceteris paribus when courts are allowed to review more legislation, since these characteristics weaken the hold of the executive on policy making.

Borrowing from Cukierman et. al. (1992), we relate central bank jurisdictional or policy independence to three "clusters"; the policy formulation, which covers the procedures for resolution of conflicts about monetary policy between the government and the $\mathrm{CB}$, and the participation of the $\mathrm{CB}$ in the budget process; the objectives of the bank; and the limitations on $\mathrm{CB}$ lending to the government. CBs with the authority to formulate monetary policy and to resist the government are more independent than otherwise. The more important is price stability in comparison to other objectives (which may clash with price stability) the higher the degree of CBI. For example A CB whose only objective is price stability is more independent than a CB whose objectives are price stability and banking stability. In turn, the latter CB is more independent than a CB whose objectives also include full employment (which may go against price stability). Finally, CBI increases with the number of limitations on CB lending to the government; cash limits are more restrictive than limits expressed as percentages of government revenue, which in turn are stricter than limits expressed as percentages of government expenditure. CBI is also higher the closer the interest rate on government debt to the market rate, the shorter the maturity of CB loans to the government and the fewer public institutions are allowed to borrow from the CB. 


\section{Control of policy objectives and policy instruments}

Goal independence refers to the degree to which an agent can choose and define its own policy objectives. Operational independence refers to an agent's freedom to choose the policy instruments in order to achieve a given policy objective. For CBs goal independence means that they can define their policy objective, like price stability, and how much priority to give to each objective in case of a multitude of objectives (price stability and employment). Instrument independence means that they can set the course of interest rates at the level deemed appropriate to achieve the objective of price stability. For judiciaries goal independence relates to the extent by which court rulings "make law", while operational independence relates to their freedom to pronounce rulings on the basis of the laws passed by the legislature. Of course judiciaries do not make laws in the sense that legislatures do. Nevertheless, to the extent that court jurisprudence interprets vague aspects of legislation, serves as a source of law and binds future court rulings, there is more goal independence than otherwise. Equally, to the extent that judiciaries conduct review of policy and may annul those acts and measures that they find incompatible with the constitution or other "higher law" (like declarations of rights, which take precedence over ordinary legislation), they come close to having some form of law making power or goal independence (albeit a "negative” one).

There is, nevertheless, an important difference between the freedom of monetary authorities and courts to set the policy instruments. Typically, the central bank can set the size of the short-run interest rates at the level it deems appropriate for achieving the objective of price stability. However, the freedom of courts to pronounce rulings is more complicated. In the case of civil disputes regarding damages to be awarded to the injured party, and in the case of criminal trials regarding fines and prison sentences, courts have the freedom to set the sums of money and prison tariffs (within the limits of the law), that is, they have operational independence similar to that of central banks. On the contrary, in cases of judicial review of policy measures, courts are restricted to what is effectively a binary choice, a yes-or-no judgment; they do not choose from a continuum. That is, courts pronounce whether a policy measure is compatible with the constitution and can therefore be enforced, or it is incompatible and thus annulled. They cannot directly 
introduce a different policy measure. On this account, when reviewing policy, courts have considerably less operational independence than central banks.

\section{Finality of decisions}

Finality of the decisions of the independent authorities relates to the ability and ease by which the government may overturn judicial rulings and monetary policy decisions it does not like. Independence rises with the difficulty of overturning the decisions of monetary and judiciary authorities. Decisions can be overturned by introducing new legislation or changing the status and power of agents whose pronouncements go against the interests of the government. The ability of the government to reverse court rulings decreases when courts are bound to follow legal precedent and when the independence of courts is provided in the constitution which, contrary to ordinary legislation, requires supermajorities to revise. This is contrasted with central bank independence which is typically founded on ordinary legislation. The latter can be repealed by a majority decision of a sitting parliament and may be easier to obtain rather than a constitutional amendment. ${ }^{19}$

\section{E. Agency costs}

Delegation of authority to unelected bodies like the judiciary and the CB, to settle public policy disputes, and to pursue monetary policy respectively, raises fundamental normative and positive dilemmas about majority rule and political accountability. In the terminology of the principal agent relation, CBI and JI generate agency costs when the independent authorities implement policies which serve its own interests rather than those of the delegating principals (the voters and their elected representatives).

The losses in democratic accountability resulting from delegation of decision making to unelected bodies vary with the type of independence granted. Goodhart and Meade (2003) argue that when politicians set the value (or range of values) of price inflation to be attained and grant the CB the independence to set the short-run interest rates to hold inflation at the specified level, as for example in the case of the Bank of England, the problem of lack of

\footnotetext{
${ }^{19}$ Transition economies provide an interesting exception to this generalisation: the constitutions of the Czech Republic, Hungary, Estonia, Poland and Russia provide for the charter of the central banks (see Salzberger and Voigt 2002).
} 
democratic control is minimised: If the majority of voters disagree with the inflation target, it can vote against the government and elect another party with an inflation target closer to the preferences of the majority. On the other hand, a problem of democratic deficit arises when the $\mathrm{CB}$ is given goal independence and sets the inflation target, as in the case of the European Central Bank, or when it can decide on the weight attached to price stability against other policy objectives (like full employment) as in the case of the Federal Reserve bank of the USA.

Similarly to central bank independence, judicial independence runs into the problems of democratic accountability. Independent courts may annul legislation which was passed by a parliamentary majority. A judiciary which is strong enough to block the policy measures enacted by the legislative majority is also strong enough to pronounce rulings which reflect and pursue the preferences (ideological or otherwise) of the judges.

It is then important to establish mechanisms to secure judicial and central bank accountability, which requires the office holders to explain their actions and rein on wayward behaviour. Accountability in the sense of requiring the office holders to give reasons and explain that their actions are justified rather than capricious is hardly controversial. But accountability in the sense of holding the office holders responsible for their decisions and possibly forcing them to bear the costs of their decisions may be more problematic, because it may infringe their independence. For it cannot be precluded that measures which aim to strengthen the accountability of an agent may be abused and weaken its independence. ${ }^{20}$

The institutional structures examined above aim to balance the competing calls for independence on the one hand, and accountability on the other. The organisational arrangements, like the selection, terms of service, disciplining and removal of officials, the requirement to explain the reasons behind their decisions, the control that the appointed officials have over the policy instruments, and the ease by which their decisions

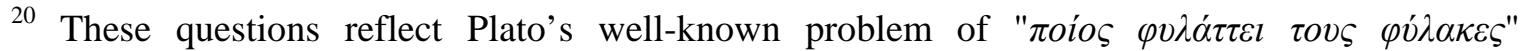
epitomised as "quis custodiet ipsos custodes?" by the Roman poet Juvenal, and translated as "who will guard the guards?", or "who watches the watchmen?" For an extensive discussion of the tension between democracy and JI see amongst others Cappelletti (1983) Seidman (1988), Ferejohn (1999) and Tiede (2006).
} 
can be reversed, comprise the solutions to a trade-off between independence and accountability. There is no "perfect" answer to this dilemma. The solutions adopted imply compromises which weigh the pros and the cons of the choices made and, as already mentioned, such solutions may vary from polity to polity.

\section{F $\quad$ Other issues}

Another issue relates to the structure of central banks and judiciaries. The judiciary is a multi-tiered structure of first-instance courts and appeal courts headed by a highest court, typically a supreme court and its administrative analogue (depending on the legal tradition of the country). Higher courts oversee the decisions of lower courts. Thus, contrary to the monetary authority the judiciary comprises a hierarchy of courts. In the first instance, sheer volume of workload justifies this division of labour. A case is typically first heard by a court of first instance and depending on the problems it raises it may go all the way to the highest court. In addition, the highest courts can also be thought as monitoring the work of lower courts. In contrast, the CB has more of a unitary structure even though in a federal state it may well comprise a number of regional offices. Thus, unlike other dimensions noted above, the difference in the structure of the monetary authorities and the judiciary may not account as a vital difference between CBI and JI.

Finally, as also noted by Goodhart (2002), CBI is an institutional novelty in comparison to JI. For the majority of nations it has been in the statutes for a relatively short period of less than a quarter of a century, even though the Federal Reserve Bank of the USA and the Bundesbank of West Germany had enjoyed significant degrees of independence from political interference for considerably longer periods. It was during the 90s and after the experience of inflation for the previous two decades when CBI was elevated from a humdrum institutional aspect of monetary policy to the top of policy reform agendas. The literature documents that CBI as defined in the charters of central banks has increased dramatically throughout the world. Given this experience, it may be more vulnerable to revision and dilution when economic circumstances change. On the contrary, judicial independence as part of the separation of powers and checks and balances goes back to the US Constitution, while its theoretical antecedents go back to the Enlightenment. 
Table 1: Summary Comparison of Central Banks \& Judiciaries

\begin{tabular}{|c|c|c|}
\hline & CENTRAL BANK & HIGHEST COURT \\
\hline Function & Monetary policy & Dispute resolution \\
\hline Goal & $\begin{array}{l}\text { Specific policy Objective: Price } \\
\text { stability } \rightarrow \text { Quantifiable = Inflation } \\
\text { target }\end{array}$ & $\begin{array}{l}\text { General \& Procedural: Rule of } \\
\text { law } \rightarrow \text { Multidimensional - } \\
\text { Difficult to quantify }\end{array}$ \\
\hline Theoretical model & $\begin{array}{l}\text { Macroeconomic model combining: } \\
\text { - } \quad \text { Quadratic loss function defined } \\
\text { over inflation \& output } \\
\text { - Lucas Supply Function relating } \\
\text { output to expected \& actual } \\
\text { inflation } \\
\text { - Stochastic environment } \\
\text { - Rational Expectations } \\
\text { - Money supply growth \& } \\
\text { inflation }\end{array}$ & $\begin{array}{l}\text { No single behavioural model - } \\
\text { Game theoretic models } \\
\text { combining: } \\
\text { - Loss function over some } \\
\text { policy variables } \\
\text { - Strategic interaction between } \\
\text { courts \& other players } \\
\text { - Stochastic environment } \\
\text { - No causal relation between the } \\
\text { policy variables chosen by the } \\
\text { courts and goal variables }\end{array}$ \\
\hline $\begin{array}{l}\text { Credibility problem } \\
\text { - Underlying conflict }\end{array}$ & $\begin{array}{l}\text { Inflation bias } \\
\text { - Government V Citizens }\end{array}$ & $\begin{array}{l}\text { Abuse of individual rights } \\
\text { - Government V Citizens }\end{array}$ \\
\hline $\begin{array}{l}\text { Political insurance } \\
\text { - Underlying conflict }\end{array}$ & $\begin{array}{l}\text { Inflation uncertainty } \\
\text { - Citizens V Citizens }\end{array}$ & $\begin{array}{l}\text { Electoral uncertainty } \\
\text { - Citizens V Citizens }\end{array}$ \\
\hline Interest group benefiting & Financial sector & Legal community \\
\hline Appointment & How far politicised? & How far politicised? \\
\hline Length of term & How long? & How long? \\
\hline Finance & Controlled by the government? & Controlled by the government? \\
\hline Transparency & How much? & How much? \\
\hline Jurisdiction & $\begin{array}{l}\text { - Procedures for resolving } \\
\text { conflicts between the CB and } \\
\text { the government } \\
\text { - Importance of price stability in } \\
\text { CB objectives } \\
\text { - Limitations of lending by the } \\
\text { CB to the government }\end{array}$ & $\begin{array}{l}\text { - } \text { Restrictions on judicial } \\
\text { competence (= subjects \& } \\
\text { cases heard by courts) } \\
\text { - } \text { Restrictions on access to } \\
\text { courts (= who can take a case } \\
\text { against the government in } \\
\text { front of a court) }\end{array}$ \\
\hline Finality of decisions & Provided by ordinary law & $\begin{array}{l}\text { - Provided by the constitution } \\
\text { - Bound by legal precedent? }\end{array}$ \\
\hline $\begin{array}{l}\text { Control of policy } \\
\text { Objectives }\end{array}$ & $\begin{array}{l}\text { Free to set the inflation target? } \\
\text { (Goal independence) }\end{array}$ & Free to “make law”? \\
\hline $\begin{array}{l}\text { Control of policy } \\
\text { instruments }\end{array}$ & $\begin{array}{l}\text { Free to set interest rates? } \\
\text { (Operational independence) }\end{array}$ & $\begin{array}{l}\text { - Civil \& Criminal Issues: } \\
\text { Free to set damages, fines \& } \\
\text { prison tariffs? } \\
\text { - Policy Review Questions: } \\
\text { Restricted to enforce or annul } \\
\text { policy measures }\end{array}$ \\
\hline Agency costs & Loss of democratic accountability & Loss of democratic accountability \\
\hline Structure & Unitary - single authority & Hierarchical authority \\
\hline Length of Experience & Short & Long \\
\hline
\end{tabular}


The analysis of this section is summarized in Table 1, which compares and contrasts the similarities and differences between the objectives, rationale and arrangements for CBI and JI. From the presentation it is clear that only some attributes of independence are directly comparable across central banks and judiciaries, while others differ in fundamental ways which may prevent systematic comparisons. In particular, the arrangements for organisational independence, namely, appointment, length and terms of service, transparency and finality of decisions, may be thought as varying along the same dimension from low to high. It is therefore similarities or differences in these arrangements, rather than the rest of the attributes, which can be used to assess whether central banks and supreme courts are characterised by analogous levels of independence.

\section{The empirical relation between $\mathrm{CBI}$ and $\mathrm{JI}$}

If the arrangements for the independence of central banks and highest judicial bodies are similar within countries but different across countries, then one should expect a positive correlation between the indices for CBI and JI. Since in practice, JI and CBI are a matter of degree than of absolute lack or presence, in the first instance the empirical validity of the proposition is tested in the present section by estimating the correlation coefficient, $\mathrm{r}$, between JI and CBI. The test is carried out for an international sample of countries on which CBI and JI indices are available.

CBI is measured by the well-known and widely used Cukierman (1992) index. The index, sometimes referred to as " $L V A W$ ", is the weighted score from aggregating various characteristics of central banks, as described in the statutes, regarding the appointment, dismissal and term of office of the governor, the relationship between the central bank and the government, authority for monetary policy and the objectives of the central bank with respect to price stability and its obligation to lend the government. The index, denoted in what follows by CUK, is taken from Cukierman, Webb, and Neypati (1992), and varies from 0 to 1 , with higher values indicating more independence. Recognizing that actual independence may differ from independence as described in legal documents Cukierman et al. (1992) have constructed an index of CBI based on the actual term of office turnover of the governors of central banks of different countries. This turnover indicator is based on the presumption that, at least above some threshold, a higher frequency of change of the governors of the central bank indicates less CBI. With high turnover, the governor of the 
central bank serves a short term and is more vulnerable to pressures from the executive. In the estimates which follow we use the average annual turnover rates for 1950-89 published by Cukierman et al. (1992). ${ }^{21}$ The index varies from 0 to 1 with higher values representing higher turnover and therefore a lower level of CBI.

For judicial independence we use the De Jure index compiled and published by Feld and Voigt (2003). De Jure judicial independence is based on the arrangements for the judicial functions found in legal documents pertaining to the highest court of a country. Its numerical value depends on whether the highest court is anchored in the constitution, how difficult is to amend the constitution, whether judicial appointments are made by the legal professionals or politicians, the term of service of judges, whether the appointment is renewable, how salaries are decided (general rules, or discretionary decisions of the government), the size of salaries in comparison to those commanded by other highly qualified legal professionals, the accessibility of the court, whether the constitution provides for judicial review of policy measures and the transparency of the deliberations of the court. Similarly to CBI, the degree of actual JI in practice may differ from the De Jure JI. For this reason Feld and Voigt (2003) also calculate a De Facto index of judicial independence. Its size depends on the effective average term length of the members of the highest court, whether judges have been removed from office before the end of their term, the number of judges serving in the highest court, the adjustment of judicial salaries to inflation, whether provisions of the constitution regarding the highest court have been changed and whether the implementation of a ruling of the court depends on some action of any other branch of government. Both the De Jure and the De Facto indices vary between zero and unity with higher values indicating more independence. In their empirical work on the effect of JI on economic growth, Feld and Voigt (2003) show that only De Facto judicial independence is conducive to growth.

Data availability constrains us to work with an international sample of 73 countries for the legal CBI and De Jure JI and with 51 observations for the actual CBI and De Facto JI. The

\footnotetext{
${ }^{21}$ Cukierman et al. (ibid.) recognise that a low turnover does not necessarily mean that the central bank is more independent, as a governor who tows the government line may stay longer in office. The issue of how likely it is that a CB governor will be replaced after a change in government is further studied in Cukierman and Webb (1995).
} 
data used are listed in the Appendix. The results from estimating the correlation coefficients and their statistical significance are presented in Table 2. Figures 1A and 1B respectively plot the De Jure JI and legal CBI indices for each country in the sample and the corresponding fitted line. Figures $2 \mathrm{~A}$ and 2B repeat the exercise for the De Facto JI and actual CBI and indices.

\begin{tabular}{|c|c|c|c|c|c|}
\hline \multicolumn{6}{|c|}{ Table 2: Correlation Coefficient "r" between CBI and JI } \\
\hline \multicolumn{6}{|c|}{ A. Full Sample } \\
\hline \multicolumn{3}{|c|}{ Variables } & \begin{tabular}{l|l|} 
& $\mathrm{r}$ \\
\end{tabular} & t-statistic & \\
\hline \multicolumn{3}{|c|}{ De Jure JI \& Legal CBI } & 0.1195 & 1.0141 & 3 \\
\hline \multicolumn{3}{|c|}{ De Facto JI \& Actual CBI } & -0.3425 & -2.5523 & 1 \\
\hline \multicolumn{6}{|c|}{ B. Breakdown by Level of Development and by Legal Origin } \\
\hline \multicolumn{6}{|c|}{ Correlation Coefficient " $r$ " between CBI and JI } \\
\hline $\begin{array}{l}\text { Developed } \\
\text { Countries }\end{array}$ & $\begin{array}{l}\text { Less } \\
\text { Developed }\end{array}$ & English & French & $\begin{array}{l}\text { German \& } \\
\text { Scandinavian }\end{array}$ & Socialist \\
\hline \multicolumn{6}{|c|}{ De Jure JI \& Legal CBI } \\
\hline $0.1911[21]$ & $0.1005[52]$ & $-0.3405[21]$ & $0.1705[25]$ & $0.4394[11]$ & $0.2289[16]$ \\
\hline 0.8486 & 0.7147 & -1.5788 & 0.8298 & 1.4677 & 0.8798 \\
\hline \multicolumn{6}{|c|}{ De Facto JI \& Actual CBI } \\
\hline $\begin{array}{ll}0.0309 \\
0.1315\end{array}$ & $\begin{array}{l}-0.0521[31] \\
-0.3264\end{array}$ & $\begin{array}{l}-0.3825[18] \\
-1.6561\end{array}$ & $\begin{array}{l}-0.3066[20] \\
-1.3670\end{array}$ & $\begin{array}{ll}0.1833[10] \\
0.5275\end{array}$ & $\begin{array}{l}\text { too few } \\
\text { observations }\end{array}$ \\
\hline \multicolumn{6}{|c|}{ Notes: $r=\sum\left(X_{i}-\bar{X}\right)\left(Y_{i}-\bar{Y}\right) \div \sqrt{\left(X_{i}-\bar{X}\right)^{2}} \sqrt{\left(Y_{i}-\bar{Y}\right)^{2}}$} \\
\hline
\end{tabular}


Figure 1A: De Jure JI (DJ) and Legal CBI (CUK) Correlation

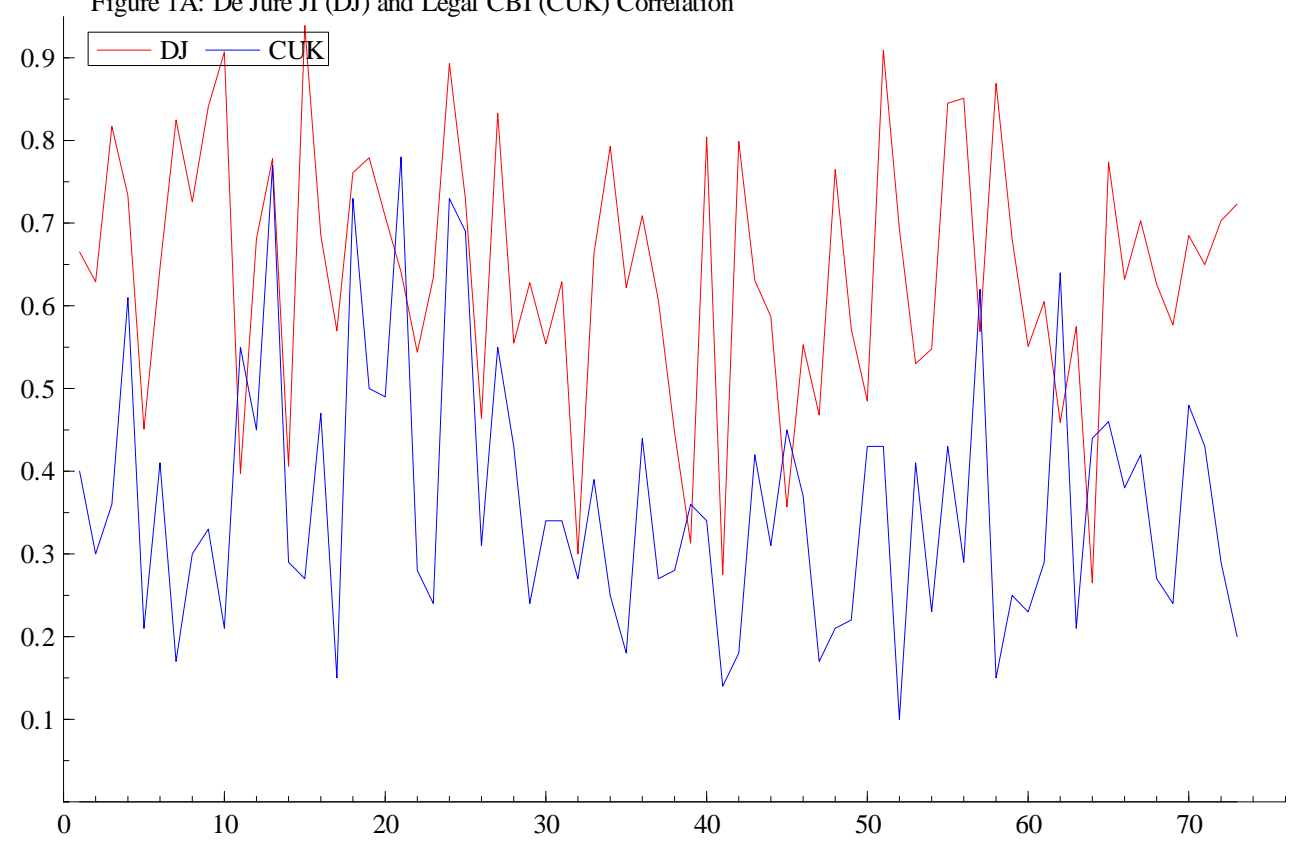

Figure 1B: De Jure JI (DJ) and Legal CBI (CUK) Fitted Values

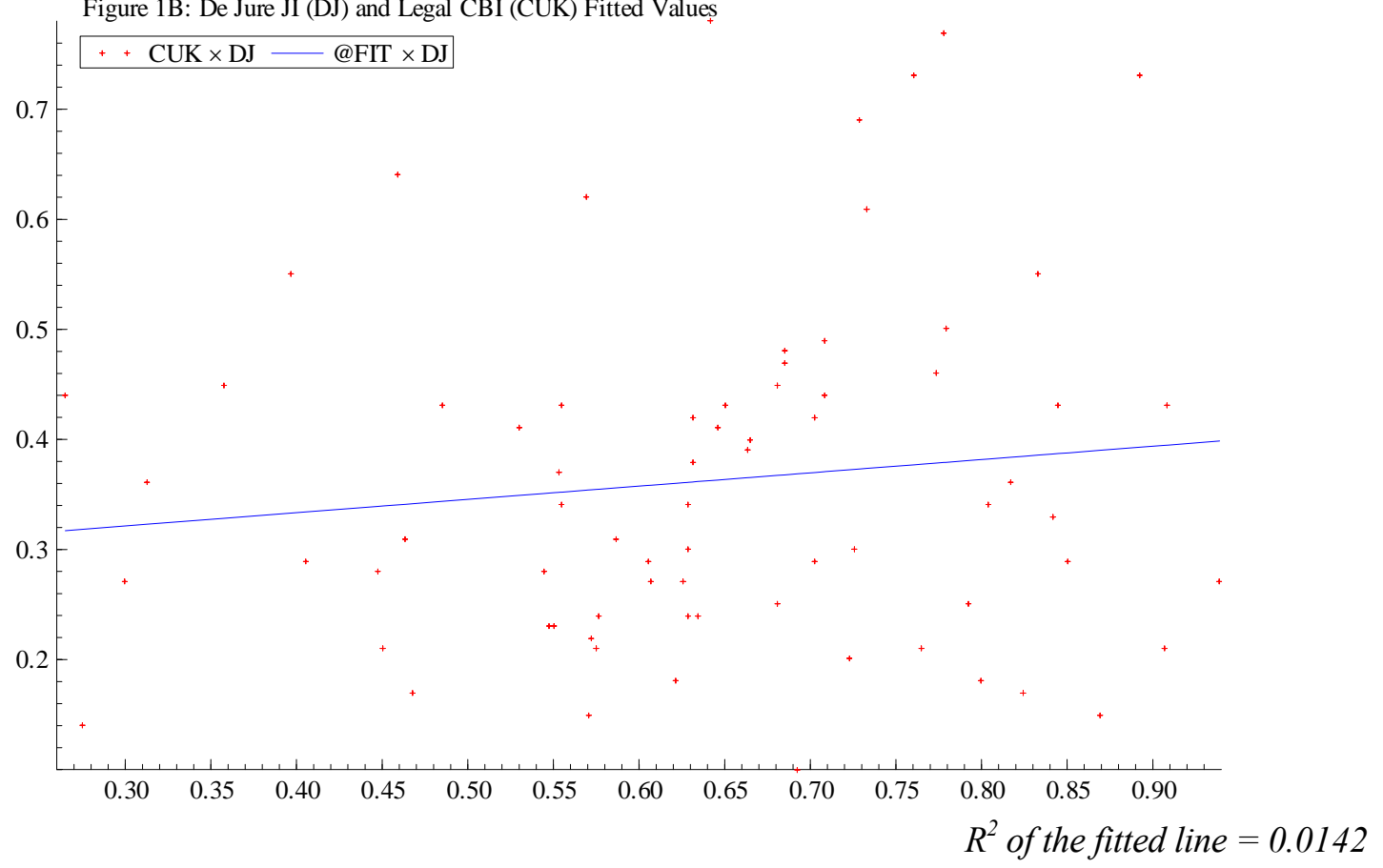




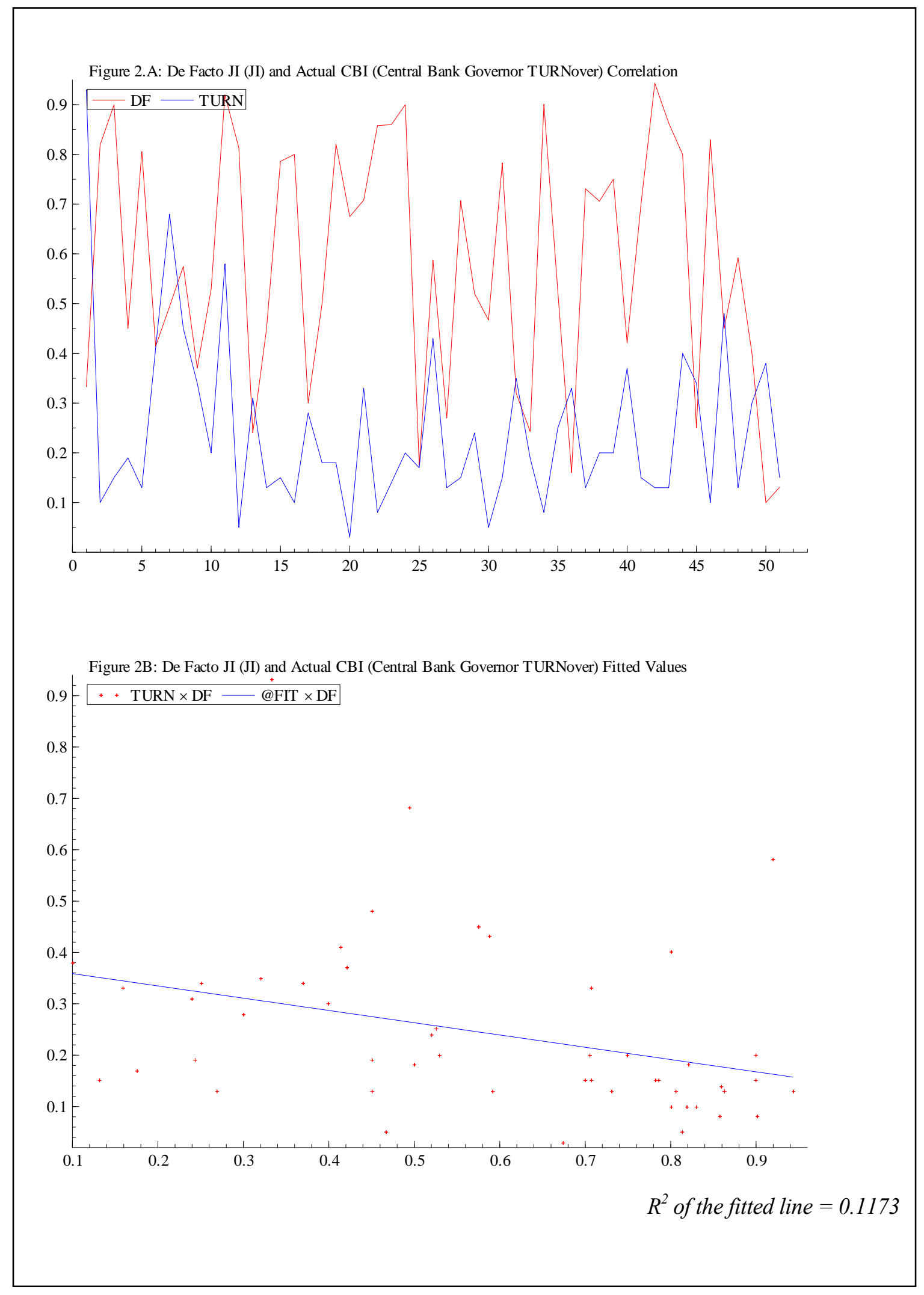


From the top panel of Table 2 it is observed that the correlation coefficient for the De Jure JI and legal CBI indices is statistically insignificant implying the lack of the presumed positive association between those two variables (first row of the Table). The theoretical prediction of legal JI and CBI complementarity based on the intuitive arguments of Goodhart (2002) and Salzberger and Voigt (2002) is rejected by the data. As further reported in bottom panel of the Table, the same rejection of a statistically significant correlation is also encountered when the countries in the full sample (a) are separated between developed ${ }^{22}$ and developing economies and (b) are divided into different subgroups according to their legal origins namely, English, French, German, Scandinavian and Socialist. ${ }^{23}$ One may take a less pessimistic view of this result and argue that the reason for the lack of statistical support is in the construction of the legal JI and CBI indices, that is, differences in the components included in the index and differences in the methodologies of measuring and aggregating the components of the indices, rather than a rejection of the hypothesis.

On the other hand, the correlation coefficient between the De Facto JI and actual CBI has an estimated value of -0.34 and is statistically significant at the 0.01 level, implying that countries characterised by higher de Facto JI are also characterised by low central bank governor turnover (Table 2A). This result is in line with the expected prior that countries with higher JI also have higher CBI. However, the estimates in Table 2.B show that none of the correlation coefficients is significant when the full sample is divided between developed and developing ${ }^{24}$ countries and between countries with different legal origins. The small number of observations for each subgroup may go some way in explaining the lack of statistical significance (especially since the subset of countries with English legal origins has the correct sign and marginally fails to be significant at the $10 \%$ level.

\footnotetext{
${ }^{22}$ Similarly, using the GMT index of CBI (Grilli et al. 1991) for 17 developed countries yields an insignificant correlation coefficient of 0.0414 with a t-statistic of 0.1605 .

${ }^{23}$ The latter test was motivated by the argument of La Porta et al (1999) that the legal origins of a country may condition the relation between the government and the judiciary, where the judicial oversight of the executive is more pronounced in the English common law tradition, less so in the French tradition of codified laws, stands in between the two in the German and Scandinavian, while in the socialist one the primary concern was the preservation of the power of the state.

${ }^{24}$ When the exercise was rerun using the Governor Turnover index for 42 developing economies published by De Haan and Kooi (2000) the coefficient of correlation was estimated at -0.0384 with a t-ratio of -0.2431 , that is, it has the expected negative sign but is statistically insignificant.
} 
All in all, the findings of this Section offer only a qualified support to the argument at the beginning of this paper about the presumed analogy between JI and CBI at the empirical levels.

\section{Conclusions}

The purpose of the present study has been to investigate the presumed analogy between central bank independence and judicial independence. The analogy is based on the argument that the same set of reasons explains delegation to central banks and courts and that in any given country similar institutional arrangements buttress the independence of central bankers and judges.

The theoretical rationales for CBI and JI were first compared. An independent central bank, which is more inflation averse than the government, also protects citizens from the tendency of politicians to manipulate the economy for political benefits, by resolving the problem of inflationary bias afflicting discretionary monetary policy. An independent judiciary applies the rule of law and resolves private disputes between citizens and protects citizens against abuses of power by the government and the "tyranny of the majority”. In addition, it was also pointed out that CBI and JI may share a common grounding in interest group politics, in the sense that the financial sector and the legal community as the main beneficiaries from low inflation and use of legal expertise respectively lobby for institutions which are independent of partisan politics. Despite these similarities, the analysis has shown that the remit of the judiciary to apply the rule of law is broader than that of price stability of the central bank and that JI plays a political insurance role which does not have a strict analogue in CBI. More specifically, JI is an integral part of the collective choice mechanism; as such it is consistent with and can be supported by opposing economic interests. On the contrary (and abstracting from the credibility role), in so far as low inflation favours some economic interests against some other, CBI may not be supported by the losers from economic stability. It was further argued that the literature on judiciary, unlike that on central banking, is nowhere near using a standard and generally accepted model of the behaviour of judges and private actors. Next, the paper turned to a comparison of the institutional arrangements underpinning JI and CBI focusing on (a) their organisation, (b) policy procedures and 
jurisdiction, (c) control of policy instruments, and (d) finality of the decision of the appointed authorities. It was concluded that arrangements about organisation and especially those regarding the appointment, length and terms of service, transparency and finality of decisions of judges and central bankers may be thought as varying along the same scale from low to high and offering the basis for investigating empirically the correlation between CBI and JI.

It is in view of the possible similarities in the organisational arrangements that the paper proceeded to obtain a quantitative assessment of the proposition that countries which grant higher JI also grant higher CBI was finally carried out. No statistically significant relation between legal JI and CBI, measured respectively by the De Jure of Feld and Voigt and Cukierman indices, was found for a sample of 73 countries. On the other hand, for a sample of 51 countries for actual JI and CBI, measured by the De Facto JI and central bank turnover indices, a negative and statistically significant coefficient of correlation was obtained indicating that higher actual JI is associated with actual higher actual CBI. Obviously, these results must be treated with caution as they represent the first tentative step towards a complete understanding of the empirical relation between JI and CBI. Nevertheless, in the light of the present study, it may be justifiable to conclude that both on theoretical and empirical grounds the relation between JI and CBI is more nuanced than the earlier informal studies in the subject have suggested.

\section{References}

Alesina, A., Summers, L.H., 1993. Central bank independence and macroeconomic performance: Some comparative evidence. Journal of Money, Credit and Banking 25:131-162

Bagheri, F.M., Habibi, N., 1998. Political institutions and central bank independence: a crosscountry analysis. Public Choice: 96, 187-204.

Berger, H. de Haan, J., Eijffinger, S.C.W., 2001. Central bank independence: An update of theory and evidence. Journal of Economic Surveys 15: 3-40

Cukierman, A., 1992. Central bank strategy, credibility and independence. Cambridge Mass, MIT Press.

Cukierman, A., 1994. Commitment through delegation, political influence and Central Bank independence. In J.A.H. de Beaufort Wijnholds, S.C.W. Eijffinger and L.H. Hoogduin (eds.), A Framework for Monetary Stability, Kluwer Academic Publishers, Dordrecht/Boston/London, 55-74.

Cukierman, A., 2006a. Central bank independence and policy results: theory and evidence. Lecture prepared for the international conference on "Stability and economic growth: The role of the central bank", Mexico City, 2005, available on the web at http://www.tau.ac.il/ alexcuk/recent_pub.html 
Cukierman, A., 2006b. Central bank independence and monetary policy making institutions. Distinguished Lecture presented at the Annual Meeting of the Chilean Economic Society , 2005 available on the web at http://www.tau.ac.il/ alexcuk/recent_pub.html

Cukierman, A., Miller, G.P. and Neyapti, B., 2002. Central bank reform, liberalization and inflation in transition economies - an international perspective. Journal of Monetary Economics 40: 237-264

Cukierman, A. and Webb, S.B., 1995. Political influence on the central bank: International evidence. The World Bank economic Review 3, 397-423.

Cukierman, A., Webb, S.B., Neyapti, B., 1992. Measuring the independence of central banks and its effects on policy outcomes. The World Bank Economic Review 6: 353-398.

Cukierman A. 2001. Accountability, Credibility, Transparency and Stabilization Policy in the Eurosystem. In: Wyplosz, C. (ed.), The Impact of EMU on Europe and the Developing Countries, Oxford University Press, Oxford, 40-75.

De Haan J., Kooi, W., 2000. Does central bank independence really matter? New evidence for developing countries using a new indicator. Journal of Banking and Finance 24: 643-664.

De Haan J., Leertouwer, E. Meijer, E. and T. Wansbeek, T., 2003. Measuring central bank independence: A latent variables approach. Scottish Journal of Political Economy 50: 326340.

De Haan, J., Van’t Hag, G.J., 1995. Variation in Central Bank independence across countries: Some provisional empirical evidence. Public Choice 85: 335-351.

Feld, L. P., Voigt, S., 2003. Economic growth and judicial independence: Cross Country evidence using a new set of indicators. European Journal of Political Economy 19: 497-527.

Ferejohn, J.A. 1999. Independent judges, dependent judiciary: explaining judicial independence. Southern California Law Review 72, 353 -384.

Ferejohn, J.A. and B.R. Weingast. 1992. A Positive Theory of Statutory Interpretation. International Review of Law and Economics 12: 263-279.

Gely, R. and Spiller P. 1990. A rational choice theory of Supreme Court statutory decisions with applications to the State Farm and Grove City cases., Journal of Law, Economics and Organization 6: 277-300.

Ginsburg, T., 2002. Economic analysis and the design of constitutional courts. Theoretical Inquiries in Law 3: 49-85.

Goodhart, C.A.E., 2002. The constitutional position of an independent central bank. Government and Opposition 37: 190-210

Goodhart, C.A.E. and Meade, E.E., 2003. Central Banks and Supreme Courts. Paper presented at Conference in Honour of Charles Freedman, Bank of Canada, 2002.

Glaeser, E.L and Shleifer, A. 2002. Legal origins. Quarterly Journal of Economics 117: 11931230

Grilli, V., Masciandaro, D., Tabellini, G., 1991. Political and monetary institutions and public financial policies in the industrial countries. Economic Policy 13: 342-392.

Hanssen, F.A. 2000. Independent courts and administrative agencies: An empirical analysis of the States. Journal of Law, Economics and Organization, 16: 534-571. -571.

Hanssen, F.A. 2004a. Is there a politically optimal level of judicial independence? American Economic Review 94: 712-799.

Hanssen, F.A. 2004b. Learning about judicial independence: Institutional change in the State courts, Journal of Legal Studies 33: 431-474.

Hayo, B. and C. Hefeker. 2002. Reconsidering central bank independence. European Journal of Political Economy 19: 653-674

Hayo, B., Voigt, S. 2007. Explaining de facto judicial independence, International Review of Law and Economics, forthcoming.

Kaufmann, D., A. Kraay and M. Mastruzzi (2005) Governance matters: Governance indicators for 1996-2004, The World Bank, Policy Research Working Paper 3630.

Keefer, P. and Sastavage, D. 2003. The limits of delegation: veto players, central bank independence, and the credibility of monetary policy. American Political Science Review 97: 407-423. 
La Porta, R., Lopez-de-Silanes, F., Shleifer, A. and Vishny, R. 1998. Law and finance. Journal of Political Economy 106: 1113-1115

La Porta, R., Lopez-de-Silanes, F., Shleifer, A. and Vishny, R. 1999. The quality of government. Journal of Law, Economics and Organization 15: 222-279

La Porta, R., Lopez-de-Silanes, F. Pop-Eleches, C., and Shleifer, A. 2004. Judicial checks and balances. Journal of Political Economy 112: 445-470.

Manne, H.G., 1997. The judiciary and free markets. Harvard Journal of Law and Public Policy 21: 11-37

Maskin, E. and J. Tirole, 2004. The politician and the judge: Accountability in government. American Economic Review. 94: 1034-1054.

McNamara, K.R., 2002. Rational fictions: Central bank independence and the social logic of delegation. West European Politics. 25: 47-76

McNollGast - McCubbins, M., G., R.G. Noll and B.R. Weingast - 1995. Politics and the Courts: A Positive Theory of Judicial Doctrine and the Rule of Law. Southern California Law Review 68: 1631-1684.

Moser, P. 1999. Checks and balances, and the supply of central bank independence. European Economic Review 43: 1569-1593

Mueller, D.C., 1996. Constitutional Democracy. Oxford University Press.

Posen, A.S. Why central bank independence does not cause inflation: There is no institutional fix for politics. In R, O’Brien (Ed.) Finance and the international economy 7. The Amex Bank Review Prize Essays. Oxford, Oxford University Press, 40-65.

Ramseyer, M. J., 1994. The puzzling (in)dependence of courts: A comparative approach. Journal of Legal Studies 33: 721-747.

Ramseyer, M. J. and E.B. Rasmussen E.B., 1997. Judicial independence in a civil law regime: the evidence from Japan. Journal of Law, Economics and Organisation 13: 259-286.

Rogoff, K., 1985. The optimal degree of commitment to an intermediate monetary target. Quarterly Journal of Economics, 100: 1169-1189

Salzberger, E.M. and Voigt, S., 2002. On the delegation of powers: with special emphasis on Central and Eastern Europe. Constitutional Political Economy. 13: 25-52.

Seidman, L.M. 1988. Ambivalence and accountability. Southern California Law Review 61, 1571-1600.

Shapiro, M. 2002. The success of judicial review and democracy. In M. Shapiro and A. Stone Sweet (Eds.) On law, politics and judicialization. Oxford University Press. Oxford, 149183.

Stephenson, M.C., 2003. When the devil turns...: The political foundations of independent judicial review. Journal of Legal Studies 32: 59-90.

Stone Sweet, A., 2002. Constitutional courts and parliamentary democracy. West European Politics. 25: 77-100.

Tridimas, G., 2004. A political economy perspective of judicial review in the European Union. Judicial appointments rule, accessibility and jurisdiction of the European Court of Justice. European Journal of Law and Economics 18: 99-116.

Tridimas, G., 2005. Judges and Taxes: Judicial review, judicial independence and the size of government. Constitutional Political Economy 16: 5-30.

Vanberg, G., 2001. Legislative-judicial relations: A game-theoretic approach to constitutional review. American Journal of Political Science 45: 345-361.

\section{Appendix}

$\begin{array}{llllll}\text { Country } & \text { DJ } & \text { DF } & \text { CUK } & \text { TOR } & \text { LO } \\ \text { Argentina } & 0.665 & 0.333 & 0.40 & 0.93 & \text { F } \\ \text { Armenia } & 0.629 & \text { n.a. } & 0.30 & \text { n.a. } & \text { So } \\ \text { Australia * } & 0.817 & 0.819 & 0.36 & 0.10 & \text { E } \\ \text { Austria * } & 0.733 & 0.900 & 0.61 & 0.15 & \text { G } \\ \text { Azerbaijan } & 0.451 & \text {.n.a. } & 0.21 & \text { n.a. } & \text { So }\end{array}$




\begin{tabular}{|c|c|c|c|c|}
\hline Bahamas & 0.646 & 0.450 & 0.41 & 0.19 \\
\hline Belgium * & 0.825 & 0.806 & 0.17 & 0.13 \\
\hline Bolivia & 0.726 & n.a. & 0.30 & n.a. \\
\hline Botswana & 0.841 & 0.414 & 0.33 & 0.41 \\
\hline Brazil & 0.907 & 0.494 & 0.21 & 0.68 \\
\hline Bulgaria & 0.397 & n.a. & 0.55 & n.a. \\
\hline Canada * & 0.681 & n.a. & 0.45 & n.a. \\
\hline Chile & 0.778 & 0.575 & 0.77 & 0.45 \\
\hline China & 0.406 & 0.370 & 0.29 & 0.34 \\
\hline Colombia & 0.939 & 0.529 & 0.27 & 0.20 \\
\hline Costa Rica & 0.685 & 0.920 & 0.47 & 0.58 \\
\hline Croatia & 0.570 & n.a. & 0.15 & n.a. \\
\hline Czech Rep & 0.761 & n.a. & 0.73 & n.a. \\
\hline Denmark * & 0.779 & 0.813 & 0.50 & 0.05 \\
\hline Egypt & 0.708 & 0.240 & 0.49 & 0.31 \\
\hline Estonia & 0.641 & n.a & 0.78 & n.a. \\
\hline Finland * & 0.544 & 0.450 & 0.28 & 0.13 \\
\hline France * & 0.634 & 0.786 & 0.24 & 0.15 \\
\hline Georgia & 0.893 & n.a & 0.73 & n.a. \\
\hline Germany * & 0.729 & 0.800 & 0.69 & 0.10 \\
\hline Ghana & 0.464 & 0.300 & 0.31 & 0.28 \\
\hline Greece * & 0.833 & 0.500 & 0.55 & 0.18 \\
\hline Honduras & 0.555 & n.a. & 0.43 & n.a. \\
\hline Hungary & 0.628 & 0.821 & 0.24 & 0.18 \\
\hline Iceland * & 0.554 & 0.675 & 0.34 & 0.03 \\
\hline India & 0.629 & 0.708 & 0.34 & 0.33 \\
\hline Indonesia & 0.300 & n.a. & 0.27 & n.a. \\
\hline Israel & 0.663 & 0.860 & 0.39 & 0.14 \\
\hline Italy * & 0.793 & 0.858 & 0.25 & 0.08 \\
\hline Japan * & 0.622 & 0.900 & 0.18 & 0.20 \\
\hline Kenya & 0.709 & 0.175 & 0.44 & 0.17 \\
\hline Korea Rep & 0.607 & 0.588 & 0.27 & 0.43 \\
\hline Lithuania & 0.447 & n.a. & 0.28 & n.a. \\
\hline Malaysia & 0.313 & 0.270 & 0.36 & 0.13 \\
\hline Мexico & 0.804 & 0.707 & 0.34 & 0.15 \\
\hline Morocco & 0.275 & n.a. & 0.14 & n.a. \\
\hline Nepal & 0.799 & 0.520 & 0.18 & 0.24 \\
\hline Netherlands * & 0.631 & 0.467 & 0.42 & 0.05 \\
\hline New Zealand * & 0.587 & 0.783 & 0.31 & 0.15 \\
\hline Nicaragua & 0.357 & 0.320 & 0.45 & 0.35 \\
\hline Nigeria & 0.553 & 0.243 & 0.37 & 0.19 \\
\hline Norway * & 0.468 & 0.901 & 0.17 & 0.08 \\
\hline Pakistan & 0.765 & 0.525 & 0.21 & 0.25 \\
\hline Panama & 0.572 & n.a. & 0.22 & n.a. \\
\hline Peru & 0.485 & 0.160 & 0.43 & 0.33 \\
\hline Philippines & 0.909 & 0.731 & 0.43 & 0.13 \\
\hline Poland & 0.693 & n.a. & 0.10 & n.a. \\
\hline Romania & 0.548 & n.a. & 0.23 & n.a. \\
\hline Russia & 0.845 & n.a. & 0.43 & n.a. \\
\hline Singapore & 0.851 & 0.421 & 0.29 & 0.37 \\
\hline Slovakia & 0.569 & n.a. & 0.62 & n.a. \\
\hline Slovenia & 0.869 & n.a. & 0.15 & n.a. \\
\hline South Africa & 0.681 & n.a. & 0.25 & n.a. \\
\hline Spain * & 0.551 & 0.750 & 0.23 & 0.20 \\
\hline Sweden * & 0.605 & 0.700 & 0.29 & 0.15 \\
\hline
\end{tabular}




$\begin{array}{llllll}\text { Switzerland * } & 0.459 & 0.943 & 0.64 & 0.13 & \mathrm{G} \\ \text { Taiwan } & 0.575 & 0.863 & 0.21 & 0.13 & \mathrm{G} \\ \text { Tanzania } & 0.265 & \text { n.a. } & 0.44 & \text { n.a. } & \mathrm{E} \\ \text { Turkey } & 0.774 & 0.800 & 0.46 & 0.40 & \mathrm{~F} \\ \text { Uganda } & 0.632 & 0.250 & 0.38 & 0.34 & \mathrm{E} \\ \text { Ukraine } & 0.703 & \text { n.a. } & 0.42 & \text { n.a. } & \text { So } \\ \text { UK * } & 0.626 & 0.830 & 0.27 & 0.10 & \mathrm{E} \\ \text { Uruguay } & 0.577 & 0.450 & 0.24 & 0.48 & \mathrm{~F} \\ \text { USA * } & 0.685 & 0.592 & 0.48 & 0.13 & \mathrm{E} \\ \text { Venezuela } & 0.650 & 0.400 & 0.43 & 0.30 & \mathrm{~F} \\ \text { Zambia } & 0.703 & 0.100 & 0.29 & 0.38 & \mathrm{E} \\ \text { Zimbabwe } & 0.723 & 0.131 & 0.20 & 0.15 & \mathrm{E}\end{array}$

Notes: $\quad *$ : classified as developed for the sample period

DJ: De Jure; DF: De Facto; CUK: Legal CBI; TOR: CB Governor Turnover LO: Legal origin; E=English, $F=$ French, $G=$ German, $S=$ Scandinavian 